\title{
THE EVOLUTION OF MODERN MARRIAGE: FROM COMMUNITY TO INDIVIDUALIZATION. THEOLOGICAL REFLECTION
}

\author{
LA EVOLUCIÓN DEL MATRIMONIO MODERNO: DE LA \\ COMUNIDAD A LA INDIVIDUALIZACIÓN. \\ UNA REFLEXIÓN TEOLÓGICA
}

\author{
SŁAWOMIR TYKARSKI \\ Nicolaus Copernicus University
}

Recibido: $12 / 10 / 2018$

Aceptado: 22/01/2019

\begin{abstract}
Statistical data from the past few decades indicate a dramatic increase in divorce rate. There are numerous reasons for this phenomenon. One of them is a growing process of individualization which exerts an enormous impact on mentality and understanding of marriage as a community. The first part of the paper concentrates on explaining what constitutes a community of marriage form a theological perspective. This reflection is based on the term communio personarum used by Karol Wojtyła/ John Paul II. It might be observed that individualization which is closely linked with egoism, hedonism, consumerism and the focus on "myself" clearly opposes the vision of marriage as a communion of persons. Pope Francis confirms this view in his apostolic exhortation Gaudete et exsultate claiming that individualism is an obstacle in attaining holiness, which is also a vocation of spouses. Therefore, the Pope calls the faithful to constrain hedonism and consumerism with which individualism is linked as these realities effectively destroy interpersonal relationships and disturb the process of building the community of marriage.
\end{abstract}


Keywords: marriage, individualization, consumerism, egoism, communion of persons, community of marriage, communio personarum, Gaudete et exsultate.

\section{RESUMEN}

Los datos estadísticos de las últimas décadas indican un aumento dramático en la tasa de divorcios. Existen numerosas razones para este fenómeno. Uno de ellos es un proceso creciente de individualización que ejerce un enorme impacto en la mentalidad y la comprensión del matrimonio como comunidad. La primera parte del artículo se concentra en explicar lo que constituye una comunidad matrimonial desde una perspectiva teológica. Esta reflexión se basa en el término communio personarum utilizado por Karol Wojtyła / Juan Pablo II. Podría observarse que la individualización que está estrechamente vinculada con el egoísmo, el hedonismo, el consumismo y el enfoque en "mí mismo" se opone claramente a la visión del matrimonio como comunión de personas. El Papa Francisco confirma este punto de vista en su exhortación apostólica Gaudete et exsultate afirmando que el individualismo es un obstáculo para alcanzar la santidad, que también es una vocación de los cónyuges. Por lo tanto, el Papa llama a los fieles a restringir el hedonismo y el consumismo con los cuales el individualismo está vinculado, ya que estas realidades efectivamente destruyen las relaciones interpersonales y perturban el proceso de construcción de la comunidad matrimonial.

Palabras clave: matrimonio, individualización, consumismo, egoísmo, comunión de personas, comunidad matimonial, communio personarum, Gaudete et exsultate.

\section{INTRODUCTION}

Analyzing statistical data from the past few decades it is possible to observe a dramatic increase in divorce rate. ${ }^{1}$ There are several reasons for this phenomenon $^{2}$ and one of them is a growing process of individualization which influences the change of mentality and understanding of marriage as a community. The aim of this paper is to show the consequences of the process of individualization for the condition of a marriage bond. The first part of the text

1 As a way of example, in Poland the number of marriages registered in 1990 was 255369 , whereas the number of divorces amounted to 42436. In 2015, 67296 couples got divorced compared to the number of registered marriages which fell to 188832. See: The Central Statistical Office, Yearbook Warszawa 2016, p. 187. In 1990 one in six marriages ended in divorce, whereas in 2015 one in three.

2 Results of the research that show impact of spirituality on marriage and divorce are very significant. See I. Platovnjak, „Divorce and Remarriage of the Divorced as a Step toward Engaging in a Life with Christ and the Church?", Bogoslovni vestnik, 3(2015) , pp. 476-481. 
will focus on a brief explanation of the meaning of marriage from a theological perspective. It will be followed by the enumeration of the main (but not all) threats that individualization poses to the durability of marriage. The final part will be devoted to the thought of Pope Francis about individualism in his apostolic exhortation Guadete et exsultate.

\section{THE ESSENCE OF MARRIAGE AS A COMMUNITY}

The paper will not present the biblical foundations of community of marriage but will concentrate on the thought of Karol Wojtyła, later Pope St. John Paul II. His approach to marriage is based on the reflection on a human person. This theological anthropology refers to the teaching of the Second Vatican Council.

The departure point for Wojtyła in his reflection on marriage was the idea taken from Gaudium et spes: "man, who is the only creature on earth which God willed for itself, cannot fully find himself except through a sincere gift of himself." ${ }^{3}$ Wojtyła calls this statement "the theological truth about man," 4 which refers to the biblical passage "So God created man in His own image; in the image of God He created him; male and female He created them" (Gen 1:27). In this view the first 'communion of persons' which Wojtyła calls a communio personarum ${ }^{5}$ is visible. This communion "sinks its roots in the natural complementarity that exists between man and woman and is nurtured through the personal willingness of the spouses to share their entire life-project, what they have and what they are."

Karol Wojtyła explains that the expression 'community' which is used in the documents of Vatican II to render a Latin term communio has a slightly

3 Vatican II, Pastoral Constitution on the Church in the Modern World Gaudium et spes, Rome, 7 December 1965, no. 24.

4 K. Wojtyła, "Rodzina jako communio personarum. Próba interpretacji teologicznej," Ateneum Kaptańskie, 3(1974), p. 349.

Wojtyła uses the term communio taken from the Eucharist which as a sacramentum communionis describes the relationship between Christ and His disciples - between God and human beings. The term communio has been used by analogy to refer to other interpersonal relations, in this case between spouses.

5 K. Wojtyła, Rodzina ..., pp. 353-354. It seems that the rapid entry of natural sciences and technology into the field of human existence demands a particular philosophical reflection. M. Oleksowicz shows in the light of the Aristotelian-Thomistic approach and the new results of scientific research, the need to develop more adequate paradigm of man as an incarnated person (the redefinition of the mind-body problem to the person-body). See M. Oleksowicz, "In search of the person. Towards a real revolution", Scientia et Fides, 6(2018), pp. 230-231; 257-259.

6 John Paul II, Apostolic Exhortation on the Role of the Christian Family in the Modern World Familiaris Consortio, Rome, 22 November 1981, no. 19. 
different meaning. The expression 'community' belongs to the same semantic level as communis. However, the term communio does not refer to what is common or emphasizes community as a certain result or even the expression of being and acting of people but communio is the way of being and acting. Thus, it is the manner (modus) which indicates being and acting in a mutual reference (not only being and acting 'together'). Through this acting and being people can confirm and affirm each other." 7 There is a semantic difference between communio translated as a 'communion' and understood not only as a 'community'. It might be said that a 'community' is a departure point, whereas a 'communion' is a target of the community of persons, namely marriage. ${ }^{8}$

Wojtyła emphasizes that a communio personarum is realized on the level of personalities, hearts, desires and minds and not only on a physical level of bodies manifested by the sexual intercourse of spouses. Communio personarum is a real union of persons, a sincere gift of spouses who mutually give and receive one another. Making oneself a sincere gift is a statement originating from the interpretation of the biblical text: "It is not good that the man should be alone; I will make him a helper as his partner" (Gen 2:18). The adjective 'alone' and the noun 'help' indicate "how fundamental and constitutive for person is relation and communion of persons. Communion of persons signifies "existence of the person 'for' the person ... existing in a particular reciprocity," ${ }^{9}$ which is a gift. Through this gift, human action and treatment of the other person are protected against utilitarianism. Affirmation allows to see the dignity of a human person "through a daily effort to promote a truly personal community, initiated and fostered by an inner communion of love." ${ }^{10}$ Furthermore, the mutual gift of spouses offers a particular richness of humankind, as a man and woman. The act of bestowing must be, however, subordinated to certain rules to protect it against profanation through egoism, concupiscence, or hedonism which may lead to the dissolution of the communion of persons and result in polygamy or the increased divorce rate. ${ }^{11}$ Thus egoism which treats a spouse as an object becomes an enemy of marriage understood as a 'communion of persons'.

$7 \quad$ K. Wojtyła, Rodzina ..., pp. 353-354.

8 See John Paul II, Man and Woman He Created Them. A Theology of the Body. Boston 2006, p. 163. In this paper, the term communio personarum is used as both the community of persons and the communion of persons, however, having in mind the abovementioned remark of Karol Wojtyła on the translation and understanding of this term.

9 John Paul II, Man and Woman ..., p. 163.

10 John Paul II, Apostolic Exhortation on the Role of the Christian Family in the Modern World Familiaris Consortio, Rome, 22 November 1981, no. 64. More about human specific and spiritual love see M. Escutia, "The will to love that makes a difference", Scientia et Fides, 6(2018), pp. 79-92.

11 "Man, however, can determine his subjectivity to such an extent that instead of being helpful it will pose a difficulty to create a communion, ... If a man is himself in an egoistic way, 


\section{THE THREAT OF INDIVIDUALIZATION FOR COMMUNIO PERSO- NARUM}

It is important to note the semantic difference between individualism and individualization. Jerzy Szacki observes that the notion of individualism should be reserved for ideologies, attitudes and beliefs which consider man as the highest good, whereas individualization is a social process which "means disembedding without reembedding" 12 .

Nowadays in a postmodern reality we are witnessing socio-cultural transformations based on individualization of societies and individuals. The growing emancipation of people and loss of ties with communities which have defined them and imposed some norms are clearly visible. The process of individualization does not concern only larger social groups but also closer interpersonal relationships in marriage and family. Individualization leads to the disintegration of traditional ties and institutions, such as marriage, privatization of morality and religious beliefs. As a result, people look for new forms of identification and identity which may lead to placing oneself and one's existence in the focus of attention as the only point of reference. Thus, an individual is isolated from the society and makes himself independent from a larger group. In marriage it results in the shift of emphasis from "we" to "I" and the transformation from the community to the group of individuals, questioning the value of the former structure.

Georg Simmel describing an individual influenced by the process of individualization observes that the point is not to gain freedom, equality and universality but to experience particularity and uniqueness: "it seems that, as soon as the ego had become sufficiently strengthened by the feeling of equality and generality ... the individual also wished to distinguish himself from other individuals. The important point no longer was the fact that he was a free individual as such, but that he was this specific, irreplaceable, given individual." 13 According to Simmel, the essential role in this process is played by money and consumerism which allow people to purchase various goods and services to distinguish them from other individuals. Observing pop-culture and

other people cannot be themselves. The subjectivity of such a person destroys the subjectivity of other people: per excessum or per defectum. In the short term, a compromise or hedonism might be a solution in marriage but in a long term, it is very difficult to live in growing tension and the relationship frequently ends in divorce." E. Ozorowski, "Małżeństwo jako komunia osób," Studia nad rodzina, 2(2002), p. 143.

12 See J. Szacki, Indywidualizm i kolektywizm, in: Encyklopedia socjologii. Suplement, Warszawa 2005, p. 86.

13 G. Simmel, Socjologia, Warszawa 1975, p. 100. 
modern advertising which apply marketing psychology the message directed to the viewer emphasizes that a person who buys the product will be special, unique and worthy of admiration and respect. In reality, something to the contrary happens as what is supposed to distinguish an individual becomes popular as other people have also purchased some product or service. Thus, the illusion of individual expression and being different than the crowd is unmasked - what is supposed to serve as a tool of individualization turns out to be conventional. The individual instead of being different reflects the mass behavior and social trends.

It should be noted that consumerism is not limited to objects only, but it encompasses interpersonal relations leading to the 'commoditization' of relationships. Frequently, people who intend to get married treat marriage as a certain type of commodity or service. They are convinced that their future spouse should ensure them a personal sense of happiness in life, which is reflected in the following expectation: "I am getting married to be happy". Such an approach may lead to the treatment of other people as objects which should ensure success in life. This is an attitude of a recipient and if the needs of a spouse are not satisfied, it may be the reason for the dissolution of marriage. "You are supposed to give me happiness. You have not fulfilled your task, so I am leaving". Such a statement reflects the attitude of a recipient and puts the individual at the centre. There is no room here for a reflection what a future spouse can do for a community of marriage, but it is important what marriage can offer to the individual. Such a mentality accepts marriage as long as it answers one's personal needs and expectations. In case they are not satisfied one's, own interest becomes more important than the good of marriage and family which results in distancing oneself from it and focusing on oneself ${ }^{14}$. Colloquially, it could be described as looking for happiness somewhere else or with a different person. It appears that this form of mentality is a common reason for a dissolution of marriage.

Apart from consumerism another characteristic manifestation of the process of individualization (promoted by the mass media and some psychological trends of humanistic provenance) is the so-called therapeutic culture focused on self-

14 Concentrating on yourself may involve making choice not on the grounds of the senses but due to being influenced by emotional impulses or emotional conditions. It often results in equating what is enjoyable to what is good- right. With having such approach, It is difficult to build a conjugal community for whole life, for a spouse feels emotional pleasure from an extramarital relationship and will treat this situation as an affirmation of its validity. See M. Mazurek, "Serce bardziej niż rozum - romantyczny postmodernizm jako wyzwanie duszpasterskie", Teologia i Człowiek, 4(2015), p. 60. 
development and self-realisation. ${ }^{15}$ People are getting self-centred and search for new psychological skills which can ensure success in life. Thus the increasing popularity of coaching and participation in various types of interpsychological courses where under the supervision of a coach the participants build (not discover) their individual potential and uniqueness. The danger of such an approach is that individuals in search of their identity learn how to create themselves applying the pattern provided by the coach instead of discovering their own potential.

Thus, individualization leads to the situation that "the individual is getting increasingly self-centered, constantly analyzing their own spiritual and emotional states and current life situation. ... It also refers to the relationship in marriage and all decisions associated with it, such as who would be the best spouse, when to have children if any, how to solve the division of household chores and responsibilities or financial decisions, etc. Due to the lack of clearcut patterns of married life these questions require reflection and redefinition."16 It is reflected in fulfilling roles in marriage. Constant search for your core might be associated with the crisis of identity. That is why, nowadays the crisis of manhood is frequently debated. Young men do not know what it means to be a man, husband and father. They often act like boys being unable to take responsibility for the relationship and family, whereas women treat motherhood as a burden. They consider their professional careers and success in life as more important than family life. These aspirations are not wrong as such; however, they might be the reason why marriage and family lose their importance in favor of personal aspirations, which is reflected in the rise of an average age of people who decide to get married and start a family.

The next danger of individualization is egoism linked with egocentrism which may lead to "the tyranny of the I". An individual focusing on his own aspirations and desires barely notices the needs of a spouse frequently devaluing them. The selfish attitude lowers empathy and people are not able to understand the situation of the other person. This makes communication difficult, opens a door to conflicts and creates obstacles in solving them. Extreme egoism may be associated with narcissism characterized by the excessive sense of one's own value and looking for interest, admiration and respect from other people. In interpersonal relationships narcissism is manifested by tendencies to manipulate and to use others for one's own needs. Relationship with a person who has a

15 See Ch. Derber, Zaistnieć w społeczeństwie, Gdańsk 2002, p. 111; M. Jacyno, Kultura indywidualizmu, Warszawa 2007, p. 253.

16 M. Olcoń-Kubicka, Indywidualizacja a nowe formy wspólnotowości, Warszawa 2009, pp. $30-31$. 
narcissistic personality is difficult because a spouse is not treated as a partner but as an "addition" for a narcist to strengthen their ego. ${ }^{17}$

The legacy of individualization in the context of married life is a deep mistrust for the institution of marriage which is manifested by an increasing popularity of cohabitation and informal relationships. ${ }^{18}$ It might be linked with egoism which has been mentioned earlier but also with the mentality of mistrust. Many young people perceive marriage as a commitment which takes away their personal freedom and limits their own private ideas about life. It is common that young spouses postpone having children in order to realize their personal aspirations and justify this attitude with the statement: "first I'd like to enjoy life, make money, travel and a child is an obstacle to all that". Thus, spouses taking care of their individual sense of happiness look for pleasure and replace a child with a pet which can be eventually sold or given away, the decision which is not possible in case of children. Speaking of mistrust, we may assume that it can be a reason for creating informal relationships which can be described as "trial relationships". Young people say: "we are going to move in together to see if it works and if we are right for each other". Quite apart from the fact that two people will always remain mystery for each other and the process of getting to know each other lasts all life it is worth observing that the wish to "put relationship to a test" is based on fear. People are afraid of trusting each other and young people seeing the growing divorce rate or unhappy marriages of their own parents or acquaintances fear commitment and taking a decision for the whole life. They are afraid that the other person will hurt them, betray and leave. Therefore, they are apprehensive of taking responsibility for themselves and their actions to repeat everyday "I want to be your spouse". If they take into consideration the experience of earlier failed "trial relationships", they even feel a deeper mistrust towards the person they try to create a new relationship with. ${ }^{19}$ It also increases mistrust to oneself as more doubts arise whether they are able to form a lasting relationship. Such a mentality and inner dilemma of mistrust

17 See S. Tykarski, “Zaburzenie osobowości przyczyną konfliktów w małżeństwie”, Studia nad rodzina, 1-2(2009), pp. 281-298.

18 It appears that in the countries representing the individualistic attitude the popularity of cohabitation/informal relationships is growing See I. Janicka, Zwiazki kohabitacyjne, in: Psychologia rodziny, red. I. Janicka, H. Liberska, Warszawa 2014, p. 265.

19 "The research has demonstrated that cohabitation has an essential influence on satisfaction, communication, trust and devotion. All these variables have turned out to be less favourable for spouses who lived together before engagement." Furthermore, premarital cohabitation lowers the quality of married life increasing the risk of divorce. For example, in Great Britain "only 4\% of informal relationships last longer than 10 years. It is estimated that $90 \%$ of cohabitations end within 5 years and 50\% within 2 years." I. Janicka, Zwiazki kohabitacyjne..., pp. $270-271,284$. 
become the sources of forming informal relationships which give an illusory feeling of comfort based on possibility of ending a relationship at any time if it does not answer their personal preferences. ${ }^{20} \mathrm{We}$ observe here an apparent paradox as the individual wishes to form a close relationship but, at the same time, is afraid of emotional engagement which entails the risk of failed relationship. ${ }^{21}$ It is a struggle between the need for autonomy and distance versus the need for experiencing emotional closeness. The need for social ties struggles with loneliness and lack of ability to build contacts. If the feeling of loneliness increases, the person may engage in an unsuitable relationship in order to satisfy the deficit of being with another person and the outcome of this decision can be a failed relationship and emotional pain which, in turn, intensify isolation and mistrust towards other people.

\section{GAUDETE ET EXSULTATE ON INDIVIDUALISM}

In his apostolic exhortation Pope Francis speaking about the call to holiness in the modern world observes that it can be achieved in community. One of the examples of such a journey in community might be marriage where "each spouse becomes a means used by Christ for the sanctification of the other" as life together "is surely a path of spiritual growth" $(141)^{22}$. According to the Pope, the obstacle in attaining holiness (also holiness in marriage) is individualism which apart from the

20 Individualization combined with the feeling of mistrust may lead to relationships with objects and forming psychological ties with them. Objects do not run the risk of failed relationships as it is in case of interpersonal relationships. In Japan an increasing number of adults form relationships with objects. They buy dolls/robots to spend time, have meals, relax with them and satisfy their sexual needs, modelling their lives according to human relations.

21 Elias speaks in a similar vein: "The advanced social differentiation that goes hand in hand with an equally advanced differentness between people or individualization, brings with it a great diversity and variability of personal relationships. One variety of them which often occurs is marked by the basic conflict of the we-less I which was mentioned earlier: a desire for emotional warmth, for affective affirmation of other people and by other people coupled to an inability to give spontaneous emotional warmth. In such cases the habit of circumspection in forming relationships has not stifled the desire to give and receive emotional warmth and for commitment in relations to others, but it has stifled the ability to give or receive them oneself. ... People seek and desire that affirmation but have lost the capacity to respond with the same spontaneity and warmth when they meet it." N. Elias, The Society of Individuals, New York, London, 2001, pp. 204-205.

It has to be noted that the main kind of interdependence of cohabitating people is emotional relationship of partners, which is an element deprived of durability. If emotions are gone and engagement does not grow, the relationship will end. See. I. Janicka, Zwiazki kohabitacyjne...,p. 263, 268, 279.

22 Cf. J. M. Pardo Sáenz, "Sentido e implicaciones de la sacramentalidad del matrimonio a la luz de Amoris Laetitia", Cauriensia, 12(2017), p. 566. 
sense of anxiety, sometimes violent, that distracts and debilitates; negativity and sullenness; the self-content bred by consumerism; egoistic acedia and all those forms of ersatz spirituality - having nothing to do with God - becomes a threat and limitation for modern culture. (see 111). Therefore, each person is called to be vigilant and to combat aggressive and selfish inclinations and behavior (see 114). People must be cautious about illusory joys of consumerism and individualism. According to the Pope, "consumerism only bloats the heart. It can offer occasional and passing pleasures, but not joy" (128). A real joy can be experienced in communion "which shares and is shared" (128). If we "focus primarily on our own needs, we condemn ourselves to a joyless existence" (see 128). Thus, life in a community of marriage liberates us "from our stale self-centredness" (136). "When we live apart from others, it is very difficult to fight against concupiscence, the snares and temptations of the devil and the selfishness of the world. Bombarded as we are by so many enticements, we can grow too isolated, lose our sense of reality and inner clarity, and easily succumb" (140). Thus "growth in holiness is a journey in community, side by side with others" (141).

The Pope cites the words of St. Mother Teresa of Calcutta who observes that "[i]f we are too concerned with ourselves, we will have no time left for others" (107). The Pope develops this thought saying that "hedonism and consumerism can prove our downfall, for when we are obsessed with our own pleasure, we end up being all too concerned about ourselves and our rights, and we feel a desperate need for free time to enjoy ourselves. We will find it hard to feel and show any real concern for those in need, unless we are able to cultivate a certain simplicity of life, resisting the feverish demands of a consumer society, which leave us impoverished and unsatisfied, anxious to have it all now" (108). Therefore, we have to realize that men are called to limit their desires and be cautious over their egoistic needs. They should constrain hedonism and consumerism as these two realities effectively destroy interpersonal relationships and disturb the process of building the community.

\section{CONCLUSION}

This paper is not an in-depth study but only an outline of the presented problem. It demands further analysis, in particular, on the clarification of individualism and the process of individualization in philosophical and theological as well as psychological and sociological contexts. Individualism should be also analyzed relying on concrete attitudes and behavior of spouses at an empirical level. It is important to acknowledge positive dimensions of individualization, such as discovering one's 
own identity, learning about personality, potential, the sense of personal value, motivation to change and enriching marriage by one's own uniqueness. ${ }^{23}$

However, uncontrolled individualization carries many risks for marriage. An individual is not able to get to know one's own individuality without community therefore individualism understood as a liberation from the society seems to be dangerous. It might be said that thanks to community people can identify themselves as individuals who despite emphasizing their individuality and unique self need acceptance of the community and society. Thus, human self and one's own identity are formed in the social reality. ${ }^{24}$ Personal individuality acquires its shape through narration and communication with others. This also applies to married life where the community of marriage does not limit the individuality of husband or wife. Their sense of individuality does not disappear in the communion of persons. On the contrary, thanks to this communion spouses can develop their personalities, improve in building relationship and complement each other.

The theological perspective presents the essence of communion of persons based on the communion of the Holy Trinity which is one God in three distinct Divine Persons. This is an excellent example to show the connection between communion and individuality (in marriage, two distinct people create one body) and a reason for further analysis of the influence of individualism on marriage. It is worth exploring the positive function of individualism in marriage as well as the destruction of a communion of persons due to individualism. The question whether these two realities exclude each other or can coexist remains open and provides opportunity for further research.

\section{REFERENCES}

Derber Ch., Zaistnieć w spoleczeństwie, Gdańsk 2002.

Elias N., The Society of Individuals, New York, London, 2001,

Escutia M., "The will to love that makes a difference", Scientia et Fides, 6(2018), pp. 79-92.

Jacyno M., Kultura indywidualizmu, Warszawa 2007.

Janicka I., "Związki kohabitacyjne," in: Psychologia rodziny, eds. I. Janicka, H. Liberska, Warszawa 2014, pp. 259-284.

23 Cf. T. Leszniewski, Od indywidualizmu do indywidualności? Teoretyczna analiza zjawiska, Toruń 2017, pp. 13-15.

24 Cf. J. Kłos, Wolność. Indywidualizm. Postęp. Liberalizm konserwatywny wobec nowoczesności, Lublin 2007, p. 281. 
John Paul II, Man and Woman He Created Them. A Theology of the Body, Boston, 2006.

Kłos J., Wolność. Indywidualizm. Postęp. Liberalizm konserwatywny wobec nowoczesności, Lublin 2007.

Leszniewski T., Od indywidualizmu do indywidualności? Teoretyczna analiza zjawiska, Torun 2017.

Mazurek M., "Serce bardziej niż rozum - romantyczny postmodernizm jako wyzwanie duszpasterskie", Teologia i Czlowiek, 4(2015), pp. 55-65.

Olcoń-Kubicka M., Indywidualizacja a nowe formy wspólnotowości, Warszawa 2009.

Oleksowicz M. "In search of the person. Towards a real revolution", Scientia et Fides, 6(2018), pp. 229-262.

Ozorowski E., "Małżeństwo jako komunia osób," Studia nad rodzina, 2(2002), pp. 129-149.

Pardo Sáenz J. M., "Sentido e implicaciones de la sacramentalidad del matrimonio a la luz de Amoris Laetitia", Cauriensia, 12(2017), p. 557-578.

Platovnjak I., „Divorce and Remarriage of the Divorced as a Step toward Engaging in a Life with Christ and the Church?" Bogoslovni vestnik, 3(2015), pp. 476-481.

Simmel G., Socjologia, Warszawa 1975.

Szacki J., Indywidualizm i kolektywizm, in: Encyklopedia socjologii. Suple-ment, Warszawa 2005, pp. 84-92.

The Central Statistical Office, Yearbook Warszawa 2016, p. 187.

Tykarski, S. "Zaburzenie osobowości przyczyną konfliktów w małżeństwie," Studia nad rodzina, 1-2(2009), pp. 281-298.

Wojtyła K., "Rodzina jako communio personarum. Próba interpretacji teologicznej," Ateneum Kaptańskie, 3(1974), pp. 347-361.

Sławomir Tykarski

Facultad de Teología

Nicolaus Copernicus University

87100 Toruń (Polonia)

https://orcid.org/0000-0002-3854-552X 